\title{
Alopecia Induced by Autologous Fat Injection into the Temporal Area: Case Report and Review of the Literature
}

\author{
Saranya Khunkhet Teerapong Rattananukrom Wilai Thanasarnaksorn \\ Poonkiat Suchonwanit
}

Division of Dermatology, Faculty of Medicine, Ramathibodi Hospital, Mahidol University, Bangkok, Thailand

\section{Keywords}

Alopecia · Filler complication · Vascular occlusion

\begin{abstract}
Alopecia secondary to facial filler injections is a highly unusual sequela. Only 2 cases of hyaluronic acid-induced alopecia have been reported to date. Accumulating evidence suggests vascular compromise as its etiology, which can be accidental intravascular injection or external compression by overfilled materials. We hereby present, to the best of our knowledge, the first case of localized nonscarring and scarring alopecia secondary to autologous fat grafting and review the literature regarding filler-induced alopecia.

(C) 2019 The Author(s)

Published by S. Karger AG, Basel
\end{abstract}




\section{Case Reports in Dermatology}

Case Rep Dermatol 2019;11:150-156

DOI: $10.1159 / 000500710$

2019 The Author(s). Published by S. Karger AG, Basel www.karger.com/cde

Khunkhet et al.: Alopecia Secondary to Facial Filler Injection

\section{Introduction}

Vascular occlusion is a rare but devastating complication of facial soft tissue augmentation. Apart from skin necrosis, it can cause permanent blindness and ischemic strokes $[1,2]$. The most common filler type associated with filler-induced iatrogenic blindness mentioned in the literature was autologous fat (48\%), followed by hyaluronic acid (HA, 23.5\%) [3]. Moreover, vascular compromise causing alopecia after filler injections is extremely rare as only 2 cases of HA-induced alopecia have been reported [4, 5]. We herein report, to the best of our knowledge, the first case of localized alopecia secondary to autologous fat grafting and review the literature regarding filler-induced alopecia.

\section{Case Report}

A healthy 36-year-old Thai woman underwent autologous fat grafting for facial augmentation under local anesthesia by a qualified medical doctor at an aesthetic clinic. A total volume of $23 \mathrm{~mL}$ of fat was grafted for the whole face by using 25-G blunt cannulas. About $2 \mathrm{~mL}$ were injected into each temple. Immediately after the procedure, she experienced an intense sharp burning pain over the right temple without skin-color changes. The only immediate post-procedure treatment received was prophylactic therapy with amoxicillin. Bluish-purple mottling of the skin was noticed along her right lateral hairline by the next day. On day 5 after fat grafting, three islands of skin necrosis with superficial crusts and clear discharge were evident on the right temple and temporoparietal scalp. The burning pain also disappeared with skin necrosis. The patient returned to the clinic to seek management. Local wound care and 3-day intravenous ceftriaxone treatment were given. Switching to oral amoxicillin/clavulanate was performed later.

On day 14, an area of hair loss had developed in a linear pattern over the right temporoparietal scalp and became progressively larger. The patient was referred to our hospital on day 35 after injection due to concerns of hair loss. Upon examination, a large, well-demarcated, nearly hairless patch, measuring $8 \times 5 \mathrm{~cm}$, with skin dyschromia was noted on the right temporoparietal scalp (Fig. 1). The hair pull test was negative. Trichoscopy showed black dots, broken hairs, exclamation mark hairs, angulated hairs (fractured hairs forming a sharp angle along the hair shaft) and V-signs at the periphery of the alopecic patch (Fig. 2a). It also revealed black dots on a background of white areas and scattered arborizing vessels in the area near the lateral hairline, suspicious for scarring alopecia (Fig. 2b).

Paired 4-mm punch biopsy specimens for horizontal and vertical sectioning were obtained from two sites of the scalp: at the lesion edge (Fig. 3a) and in the area of suspected scarring alopecia (Fig. 3b). Histopathology of both sections demonstrated a total or near-total shift of anagen to catagen/telogen follicles, clumps of pigment within follicles and stelae, focal necrotic keratinocytes in the follicular epithelium, as well as mild perivascular and perifollicular lymphocytic infiltrates. Histopathology of the area of suspected scarring alopecia (Fig. 3b) also showed a decreased number of hair follicles, dermal pools of adipocytes admixed with inflammatory cells, and some adipocytes within the follicular epithelium. Foreign material in the vessel lumen, vascular necrosis, or fibrosis was not present in both sections. 
Vascular compromise causing alopecia was diagnosed. The occlusion most likely happened in both the parietal and frontal branches of the right superficial temporal artery. In addition to patient reassurance, $5 \%$ minoxidil solution was prescribed for twice-daily use. Three months after fat grafting, hair regrowth, with approximately $50 \%$ of the native hair density, was noticeable all over the alopecic patch, except in the area of previous skin necrosis. New hair growth was restored to full density at 6 months after the procedure (Fig. 1).

\section{Discussion}

Alopecia secondary to facial filler injections is a highly unusual sequela. Only 3 cases, including the current case, have been reported to date. The filler material used in the first 2 cases was HA while autologous fat was utilized in the current case. Accumulating evidence suggests vascular compromise as its etiology, which can be accidental intravascular injection or external compression by overfilled materials. Initial manifestations of intra-arterial occlusion include disproportionate pain and immediate skin blanching. The affected sites may later develop livedo reticularis, blue-black discoloration of the skin, and ulceration with or without scar formation [6]. Vascular compression by a large volume of injected materials can manifest a delayed onset of arterial occlusion [7].

All 3 reported cases had a similar clinical presentation (Table 1). Skin necrosis and alopecia occurred after temple augmentation, probably resulting from a vascular blockage in the parietal branch of the superficial temporal artery. All cases experienced a persistent high-intensity pain immediately after the procedure, followed by a varying degree of skin necrosis with crust formation as well as alopecia, in the anatomical territories of the superficial temporal artery. The onset of alopecia was about 2 weeks after injection, presenting as a solitary, well-demarcated, nearly hairless patch. Spontaneous hair regrowth developed in about 3 months, gaining full hair density in about 6 months after injection. Nonetheless, permanent hair loss occurred in the area of previous skin necrosis. The patients' manifestations, treatment, and outcomes are shown in Table 1.

Regarding histopathology, all cases demonstrated a total or near-total shift to catagen/telogen follicles, pools of foreign material in the dermis, and mild infiltration of inflammatory cells, mainly lymphocytes and macrophages. Other partially observable features included pigment casts in the follicles or fibrous streamers, trichomalacia, and foreign material within the vascular lumen. Trichoscopy of filler-induced alopecia was first described in the current case, representing two different trichoscopic patterns. The features of dystrophic hairs resembling alopecia areata, such as broken hairs, exclamation mark hairs, and angulated hairs [8], were observed, particularly in the peripheral rim of the alopecic patch. White areas and scattered arborizing vessels were noticed in the area of previous skin necrosis, where early-stage scarring alopecia was suspected.

Clinical presentations, histopathology, and clinical course of filler-induced alopecia are relatively similar to those of pressure-induced alopecia $[9,10]$. However, patients with hair loss secondary to filler injections have a shorter onset time of alopecia after injection compared with those after pressure. Furthermore, occurrence rates of skin necrosis and permanent hair loss are greatly higher in cases of filler-induced alopecia [11-13]. This might imply that filler-induced and pressure-induced alopecias share the same etiology, which is vascular 
compromise leading to local tissue hypoperfusion and hypoxia, but with a different degree of ischemic damage.

We speculate that disturbances in the pattern of hair growth depend basically on the degree of scalp ischemia. In the ischemic core, acute vascular occlusion abruptly interrupts vital blood supply to the growing hair follicles, contributing to sudden termination of the anagen phase and uniform entry into the catagen phase. Consequently, dystrophic catagen hair follicles with rapid shedding are formed, possibly due to ischemia-induced apoptosis. As for the ischemic periphery, the damage may not be severe enough to convert hair follicles into different growth phases; however, dystrophic anagen hairs are produced.

Filler-induced alopecia is generally reversible within 6 months, except for the site of previous skin necrosis. The subsequent development of permanent alopecia is suspected to result from irreversible damage to hair follicle stem cells located in the bulge region by the necrotic process [14]. As reversibility of hair loss is dependent on having adequate collateral flow and sufficient reperfusion to maintain viable scalp tissue, early recognition and immediate management of vascular compromise are keys for hair preservation.

Mainstays of treatment for filler-induced vascular compromise include hyaluronidase injection (in cases of HA) to minimize the remaining material and reduce pressure on the occluded vessel, warm compresses and nitroglycerin paste application to promote vasodilation, massaging to break a focal obstruction, and oral acetylsalicylic acid to prevent further clotting. Other strategies are systemic or intralesional steroids to reduce inflammation in the injured tissue which might cause a greater degree of vascular compromise, and hyperbaric oxygen therapy to keep tissue viable [15-17].

In conclusion, although filler-induced vascular compromise leading to alopecia is a rare event, it can leave permanent hair loss. Early detection and prompt treatment to enhance vascular reperfusion are of paramount importance for hair regrowth.

\section{Statement of Ethics}

The authors have no ethical conflicts to disclose.

\section{Disclosure Statement}

The authors have no conflicts of interest to declare.

\section{Author Contributions}

All named authors meet the International Committee of Medical Journal Editors (ICMJE) criteria for authorship of the manuscript, take responsibility for the integrity of the work as a whole, and have given final approval to the version to be published. 


\section{References}

1 Breithaupt AD, Jones DH, Braz A, Narins R, Weinkle S. Anatomical basis for safe and effective volumization of the temple. Dermatol Surg. 2015 Dec;41 Suppl 1:S278-83.

2 van der Meulen JJ, Willemsen J, van der Vlugt J, Nazir PR, Hilling D, Mathijssen IM, et al.; Dutch Craniofacial Unit. On the origin of bitemporal hollowing. J Craniofac Surg. 2009 May;20(3):752-6.

3 Beleznay K, Carruthers JD, Humphrey S, Jones D. Avoiding and treating blindness from fillers: a review of the world literature. Dermatol Surg. 2015 Oct;41(10):1097-117.

4 Gan SD, Itkin A, Wolpowitz D. Hyaluronic acid-induced alopecia: a novel complication. Dermatol Surg. 2013 Nov;39(11):1724-5.

5 Yang Q, Qiu L, Yi C, Xue P, Yu Z, Ma X, et al. Reversible alopecia with localized scalp necrosis after accidental embolization of the parietal artery with hyaluronic acid. Aesthetic Plast Surg. 2017 Jun;41(3):695-9.

6 DeLorenzi C. Complications of injectable fillers, part 2: vascular complications. Aesthet Surg J. 2014 May;34(4):584-600.

7 Hirsch RJ, Lupo M, Cohen JL, Duffy D. Delayed presentation of impending necrosis following soft tissue augmentation with hyaluronic acid and successful management with hyaluronidase. J Drugs Dermatol. 2007 Mar;6(3):325-8.

8 Khunkhet S, Vachiramon V, Suchonwanit P. Trichoscopic clues for diagnosis of alopecia areata and trichotillomania in Asians. Int J Dermatol. 2017 Feb;56(2):161-5.

9 Khalaf H, Negmi H, Hassan G, Al-Sebayel M. Postoperative alopecia areata: is pressure-induced ischemia the only cause to blame? Transplant Proc. 2004 Sep;36(7):2158-9.

10 Kosanin RM, Riefkohl R, Barwick WJ. Postoperative alopecia in a woman after a lengthy plastic surgical procedure. Plast Reconstr Surg. 1984 Feb;73(2):308-9.

11 Loh SH, Lew BL, Sim WY. Pressure alopecia: clinical findings and prognosis. J Am Acad Dermatol. 2015 Jan;72(1):188-9.

12 Sano DT, Kakizaki P, Anzai A, Donati A, Valente NY, Romiti R. Headband pressure alopecia: clinical, dermoscopy, and histopathology findings in four patients. Int J Dermatol. 2018 Feb;57(2):237-9.

13 Hanly AJ, Jorda M, Badiavas E, Valencia I, Elgart GW. Postoperative pressure-induced alopecia: report of a case and discussion of the role of apoptosis in non-scarring alopecia. J Cutan Pathol. 1999 Aug;26(7):357-61.

14 Harnchoowong S, Suchonwanit P. PPAR- $\gamma$ agonists and their role in primary cicatricial alopecia. PPAR Res. 2017;2017:2501248.

15 Urdiales-Gálvez F, Delgado NE, Figueiredo V, Lajo-Plaza JV, Mira M, Moreno A, et al. Treatment of soft tissue filler complications: expert consensus recommendations. Aesthetic Plast Surg. 2018 Apr;42(2):498-510.

16 Chiang YZ, Pierone G, Al-Niaimi F. Dermal fillers: pathophysiology, prevention and treatment of complications. J Eur Acad Dermatol Venereol. 2017 Mar;31(3):405-13.

17 Beer K, Downie J, Beer J. A treatment protocol for vascular occlusion from particulate soft tissue augmentation. J Clin Aesthet Dermatol. 2012 May;5(5):44-7. 


\section{Case Reports in Dermatology}

Case Rep Dermatol 2019;11:150-156

DOI: $10.1159 / 000500710$

(C) 2019 The Author(s). Published by S. Karger AG, Basel www.karger.com/cde

Khunkhet et al.: Alopecia Secondary to Facial Filler Injection
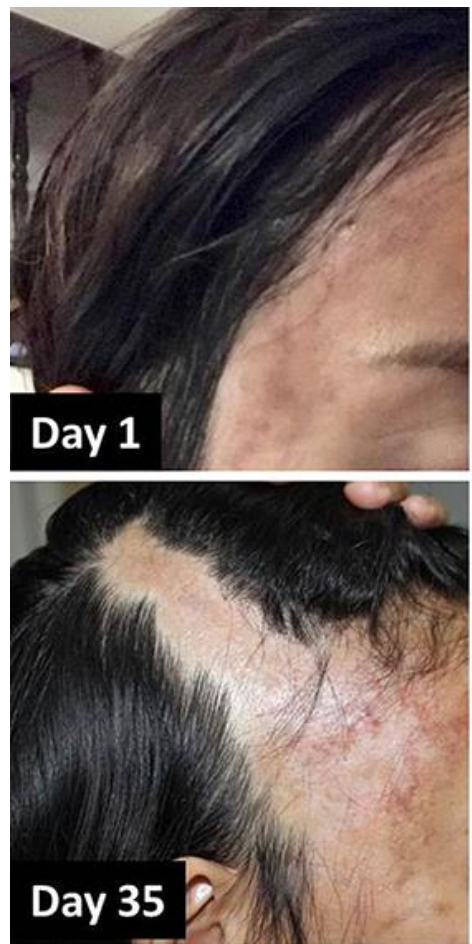
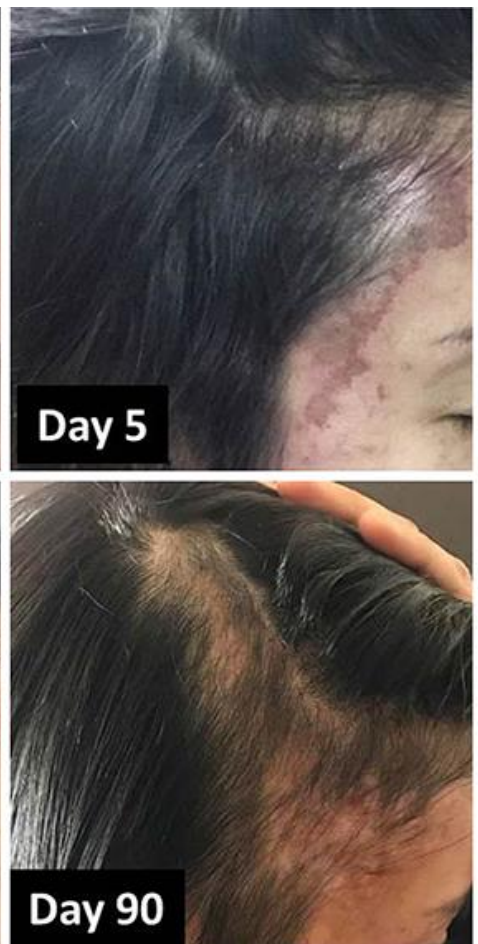
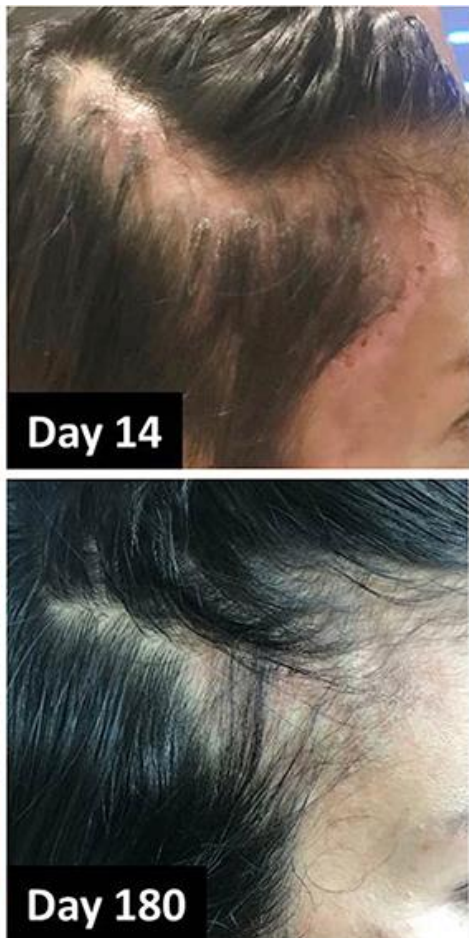

Fig. 1. Vascular compromise after autologous fat grafting into the temple leading to skin necrosis and alopecia, which is generally reversible within 6 months, except for the area of previous skin necrosis.
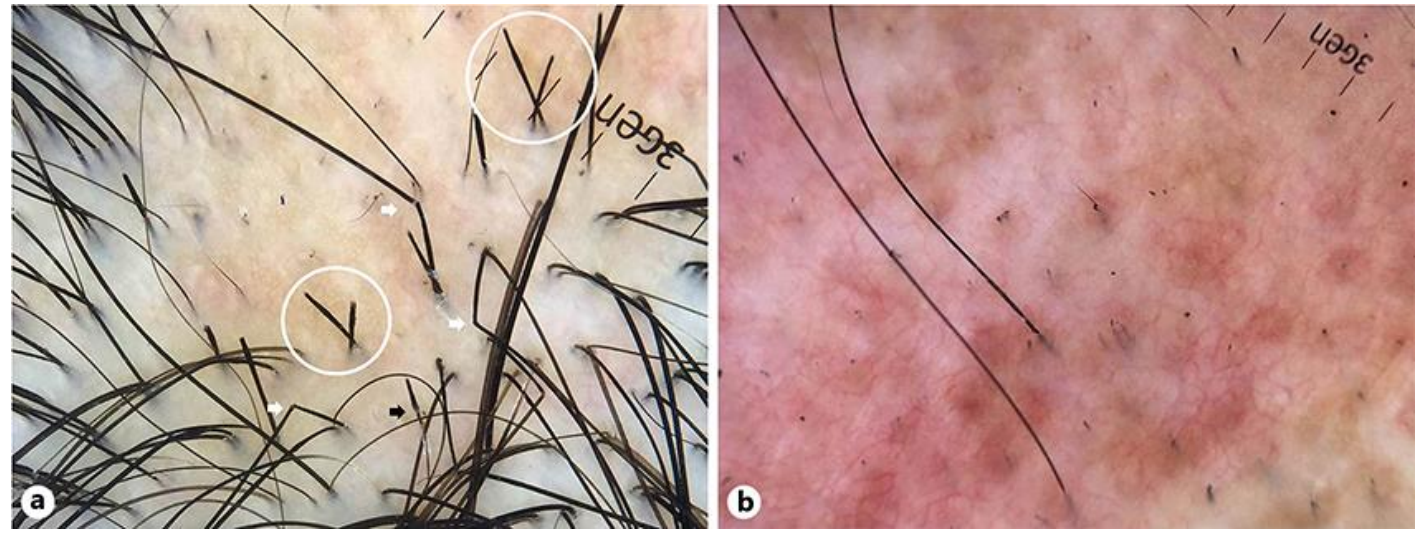

Fig. 2. Trichoscopy of filler-induced alopecia. Magnification, $\times 20$. a At the periphery of the alopecic patch, black dots, broken hairs, exclamation mark hairs (black arrow), angulated hairs (white arrows), and Vsigns (circles) are evident. b At the site of previous skin necrosis, trichoscopy shows black dots on a background of white areas and scattered arborizing vessels. 


\section{Case Reports in Dermatology}
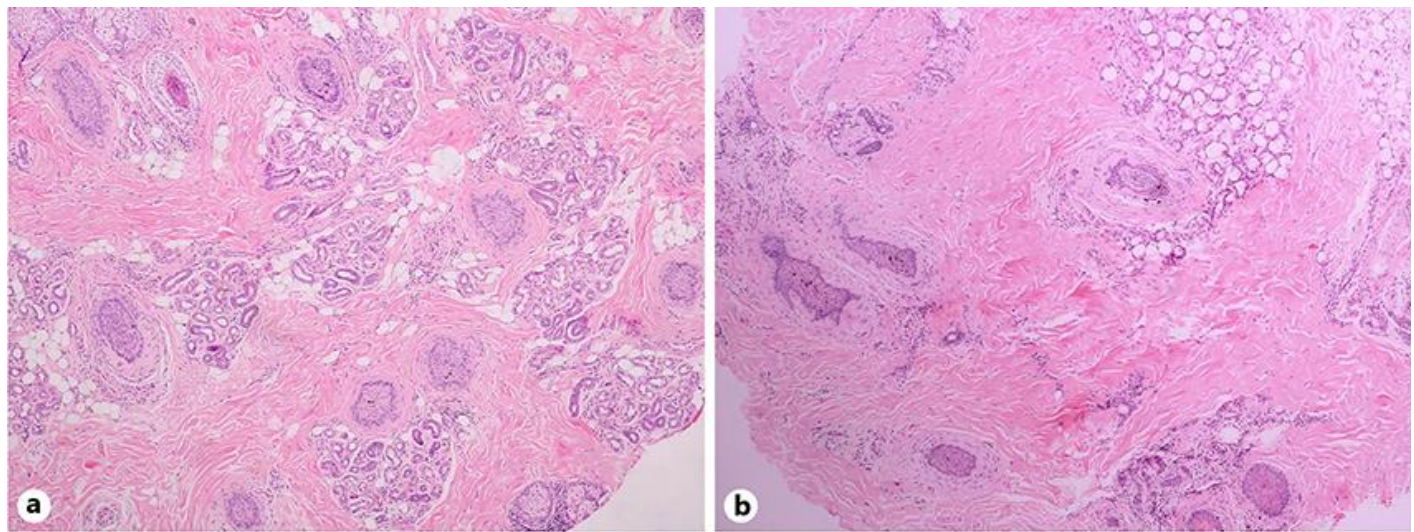

Fig. 3. Histopathology of filler-induced alopecia. Hematoxylin-eosin stain. Original magnification, $\times 10$. a Specimen from the periphery of the alopecic patch shows a near-total shift to catagen/telogen follicles and pigment casts in follicles. b Specimen from the site of previous skin necrosis reveals a decreased number of hair follicles, a total shift to catagen/telogen follicles, pigment casts in the follicles and stelae, dermal deposits of adipocytes, and mild inflammatory infiltrates.

Table 1. Cases of vascular compromise causing alopecia after soft tissue augmentation into the temple

\begin{tabular}{|c|c|c|c|c|c|c|c|}
\hline Ref. & $\begin{array}{l}\text { Age, } \\
\text { years }\end{array}$ & $\begin{array}{l}\text { Type of } \\
\text { filler }\end{array}$ & $\begin{array}{l}\text { Volume } \\
\text { side }\end{array}$ & rClinical presentation & Histopathology & Treatment & Evolution \\
\hline $\begin{array}{l}\text { Gan } \\
\text { et al. [4] }\end{array}$ & 58 & HA & $6 \mathrm{~mL}$ & $\begin{array}{l}\text { Immediate: severe persis- } \\
\text { tent pain } \\
\text { Day 15: a well-defined alope- } \\
\text { cic patch with scattered } \\
\text { superficial crusts }\end{array}$ & $\begin{array}{l}\text { Near-total shift out of anagen } \\
\text { Focal trichomalacia } \\
\text { Dermal pools of mucin } \\
\text { Mucin in vascular lumen } \\
\text { Sparse inflammatory infiltrate }\end{array}$ & $\begin{array}{l}\text { Intralesional tri- } \\
\text { amcinolone }(5 \\
\mathrm{mg} / \mathrm{mL})\end{array}$ & $\begin{array}{l}\text { Day 90: hair regrowth } \\
\text { with a small patch of per- } \\
\text { manent alopecia }\end{array}$ \\
\hline $\begin{array}{l}\text { Yang } \\
\text { et al. [5] }\end{array}$ & 27 & HA & $6.5 \mathrm{~mL}$ & $\begin{array}{l}\text { Immediate: severe persis- } \\
\text { tent pain } \\
\text { Day 9: skin necrosis with } \\
\text { thin eschar } \\
\text { Day 15: a well-defined alope- } \\
\text { cic patch with a central } \\
\text { necrotic wound }\end{array}$ & $\begin{array}{l}\text { Shift out of anagen } \\
\text { Dermal deposits of mucin } \\
\text { Mild inflammatory infiltrate }\end{array}$ & $\begin{array}{l}\text { FGF gel } \\
2 \% \text { MNX } \\
\text { spray }\end{array}$ & $\begin{array}{l}\text { Day 74: hair regrowth } \\
\text { with a central patch of } \\
\text { permanent alopecia } \\
\text { Day 209: restoration of } \\
\text { full hair density }\end{array}$ \\
\hline $\begin{array}{l}\text { Current } \\
\text { case }\end{array}$ & 36 & $\begin{array}{l}\text { Autolo- } \\
\text { gous fat }\end{array}$ & $2 \mathrm{~mL}$ & $\begin{array}{l}\text { Immediate: moderate persistent } \\
\text { pain } \\
\text { Day 1: livedo reticularis } \\
\text { Day 5: skin necrosis with superficial } \\
\text { crusts } \\
\text { Day 14: a well-defined alope- } \\
\text { cic patch with necrotic crusts }\end{array}$ & $\begin{array}{l}\text { Near-total shift out of anagen } \\
\text { Pigment casts in follicles/stelae } \\
\text { Follicular necrotic keratinocytes } \\
\text { Mild inflammatory infiltrates } \\
\text { Dermal pools of adipocytes } \\
\text { Adipocytes in follicles }\end{array}$ & $\begin{array}{l}5 \% \text { MNX } \\
\text { lotion }\end{array}$ & $\begin{array}{l}\text { Day 90: hair regrowth and } \\
\text { patches of permanent alo- } \\
\text { pecia } \\
\text { Day 180: restoration of } \\
\text { full hair density }\end{array}$ \\
\hline
\end{tabular}

HA, hyaluronic acid; FGF, fibroblast growth factor; MNX, minoxidil. 